\title{
STRATEGI KOMUNIKASI DALAM KAMPANYE DIET KANTONG PLASTIK OLEH GIDKP DI INDONESIA
}

\author{
Hayatullah Kurniadi ${ }^{1}$ \& Mohamad Hizasalasi ${ }^{2}$
}

\author{
Fakultas Ilmu Sosial dan Ilmu Politik Universitas Abdurrab, Indonesia1; \\ STISIP Persada Bunda, Indonesia ${ }^{2}$ \\ Email: hayatullahkurniadi@univrab.ac.id
}

\begin{abstract}
Abstrak
Penelitian ini berfokus pada strategi komunikasi yang dilakukan oleh GIDKP dalam kampanye Diet Kantong Plastik. Komunikasi menjadi bagian yang sangat vital dalam melaksanakan kampanye Diet Kantong Plastik. Siklus penggunaan kantong plastik di tengah masyarakat semakin hari semakin cepat dan mayoritas tidak bertanggung jawab. Kantong plastik yang menumpuk dan menjadi sampah tentu menjadi penyebab kerusakan lingkungan dan permasalahan kesehatan. Penelitian ini menghasilkan data deskriptif. Metode pengumpulan data dengan wawancara dan penelusuran dokumen. Hasil penelitian menunjukkan bahwa setiap unsur dalam komunikasi yang meliputi komunikator, pesan, media, komunikan dan efek sangat penting dalam usaha menyadarkan masyarakat untuk bijak menggunakan plastik. Strategi komunikasi melebur di dalam pendekatan regulasi/ advokasi, edukasi dan fasilitasi yang menjadi titik poin kampanye GIDKP. Perhatian penting pada setiap unsur komunikasi direncanakan dengan pertimbangan-pertimbangan yang saling menunjang dan dimiliki oleh GIDKP.
\end{abstract}

Kata Kunci: Strategi Komunikasi, Kampanye dan Diet Kantong Plastik

\begin{abstract}
This research focused on the communication strategy undertaken by GIDKP in diet plastik bags campaign. Communication become a very important in implementing diet plastic bags campaign. the use cycling of plastic bag in the society increasingly faster and the majority does not responsible. The accumulation of plastic bags and becoming trash will be the environmental and health problems. This research resulted the descriptive data. Data were collected by interviews method and tracing documents. The research results showed that every element in communication which includes communicator, message, media, communicant and effects were very important in efforts to made people aware of the wise use of plastic. The communication strategy fusible in approach regulations and advocacy, education and facilitation were become stressing points of GIDKP campaign. An important concern on every element communication were planned with considerations of mutual support and owned by GIDKP.
\end{abstract}

Keywords: Communication Strategy, Campaigns and Diet Plastic Bags

\section{PENDAHULUAN}

Kantong plastik semakin menjadi sorotan dewasa ini. Sorotan ini mengarah pada banyaknya problem yang diakibatkan oleh kantong plastik. Kantong plastik menyebabkan kotornya lingkungan, tersumbatnya selokan dan badan air yang dapat mengakibatkan 
banjir, termakan oleh hewan dan rusaknya ekosistem di sungai dan di laut serta menjadi penyebab banyakanya permasalahan kesehatan manusia.

Jika ditelisik, mengapa hal tesebut terjadi, maka persoalan ini tentu mengarah pada perilaku manusia yang tidak bijak dalam menggunakan kantong plastik. Kantong plastik hanya menjadi barang sekali pakai kemudian dibuang dan pada akhirnya di sinilah bencana datang. Kantong plastik menumpuk dan menjadi sampah. Begitulah siklus penggunaan kantong plastik terus-menerus yang menjadi malapetaka kehidupan manusia.

Sebuah langkah jitu untuk menekan angka konsumsi kantong plastik di Indonesia dilakukan oleh Gerakan Indonesia Diet Kantong Plastik (GIDKP) yang berdomisili di Bandung. Kampanye yang diusung adalah kampanye Diet Kantong Plastik. Diet di sini memiliki makna bijak dalam mengonsumsi. GIDKP berkampanye agar setiap orang dapat secara bijak menggunakan kantong plastik dalam kehidupan sehari-hari. Kampanye ini bertujuan untuk mengurangi penggunaan kantong plastik secara berlebihan oleh masyarakat (dietkantongplastik.info: 2017).

Strategi komunikasi menjadi bagian penting dalam kampanye Diet Kantong Plastik. Tanpa adanya strategi komunikasi, maka pesan yang ingin disampaikan tidak akan diterima khalayak. Artinya, tujuan yang ingin dicapai juga tidak akan didapat.

Penelitian ini bertujuan untuk menemukan data empiris tentang strategi komunikasi dalam kampanye Diet Kantong Plastik oleh Gerakan Indonesia Diet Kantong Plastik (GIDKP) di Indonesia, sedangkan manfaat yang dapat diberikan adalah sebagai bahan informasi dan referensi bagi pihak lain yang memiliki ketertarikan terhadap kajian yang serupa.

\section{KERANGKA TEORI}

\section{Strategi Komunikasi}

Secara etimologi, strategi berasal dari bahasa Yunani Klasik, yaitu stratos yang artinya tentara dan agein yang berarti memimpin. Dengan demikian strategi dimaksudkan adalah memimpin tentara. Lalu muncul kata strategos yang memiliki pengertian pemimpin tentara pada tingkat atas. Jadi strategi adalah konsep militer yang bisa diartikan sebagai seni perang para jenderal atau suatu rancangan yang terbaik untuk memenangkan peperangan. MartinAnderson (1968) mendefinisikan strategi adalah seni di mana melibatkan kemampuan inteligensi/ pikiran untuk membawa semua sumber daya yang tersedia dalam mencapai tujuan dengan memperoleh keuntungan yang maksimal dan efisien (Cangara, 2014).

Kemudian Istilah komunikasi didefinisikan oleh Everett M. Rogers pada tahun 1985 digunakan sebagai landasan awal dalam memakni komunikasi dalam tulisan ini. Dia mengatakan bahwa komunikasi adalah proses di mana suatu ide dialihkan dari sumber kepada satu penerima atau lebih dengan maksud untuk mengubah tingkah laku (Cangara, 2014). Pengertian ini bermaksud menjelaskan bahwa di samping memaknai komunikasi sebagai sebuah proses, akan tetapi ada strategi tertentu yang dilakukan dalam berkomunikasi sehingga perubahan dapat terjadi pada diri komunikan.

Strategi komunikai berguna untuk memecahkan permasalahanpermasalahan yang identik dengan komunikasi. Sehingga Rogers (1982) menekankan pengertian strategi komunikasi sebagai suatu rancangan yang dibuat untuk mengubah tingkah 
laku manusia dalam skala yang lebih besar melalui transfer ide-ide baru.

Jika dilihat dari akarnya, strategi komunikasi merupakan turunan dari kebijakan komunikasi dan perencanaan komunikasi. Konsep strategi komunikasi diletakkan sebagai bagian dari perencanaan komunikasi dalam mencapai tujuan komunikasi yang diinginkan, sedangkan perencanaan strategic tidak lain adalah kebijaksanaan komunikasi dalam tatanan makro untuk program jangka panjang. Pemilihan strategi merupakan langkah krusial yang memerlukan penanganan secara hati-hati dalam perencanaan komunikasi, sebab jika salah/ keliru maka hasilnya dalah kerugian (Cangara, 2014).

Dengan demikian, maka pengertian strategi komunikasi adalah:

1. Paduan perencanaan komunikasi dengan manajemen komunikasi untuk mencapai tujuan yang ditetapkan (Misnawati, 2013).

2. Kombinasi yang terbaik dari seluruh elemen komunikasi (apa yang disebut dalam formula Laswell) yang dirancang untuk mencapai tujuan komunikasi yang optimal.

Strategi yang dijalankan dalam perencanaan komunikasi kembali kepada elemen dari komunikasi itu sendiri seperti yang dikemukan oleh Laswell dengan formula who says what in which channel to whom and with what effect.

\section{Strategi Komunikator}

Komunikator sebagai pelaku utama aktivitas komunikasi, sehingga mereka dituntut memiliki keterampilan berkomunikasi yang kaya akan ide dan kreatif. Jika suatu program komunikasi tidak berjalan dengan baik maka kesalahan utamanya terletak pada komunikatornya. Pemilihan/ penetapan komunikator sangat penting, karena elemen-elemen berikutnya sangat dipengaruhi oleh strategi ini.

Komunikator harus memiliki kredibilitas, daya tarik dan kekuatan agar mampu mencapai sasaran komunikasi. Kredibilitas adalah seperangkat persepsi tentang kelebihan-kelebihan yang dimiliki seorang komunikator sehingga bisa diterima oleh khalayak sasaran. Berlo (1962) menjelaskan tentang kredibilitas bisa muncul jika seorang komunikator memiliki keterampilan berkomunikasi (communication skill), pengetahuan yang luas (knowledge), sikap jujur dan bersahabat (attitude), serta mampu beradaptasi dengan sistem sosial budaya (social and cultural system) masyarakat yang dihadapinya disamping itu semua, sorang komunikator juga harus memiliki daya tarik (attractiveness). Daya tarik ini bisa dalam bentuk bicara yang sopan, murah tersenyum cara berpakaian yang menarik dan postur tubuh yang gagah.

\section{Strategi Khalayak}

Memahamai masyarakat yang menjadi target sasaran program komunikasi merupakan hal yang sangat penting. Seluruh kegiatan komunikasi pada akhirnya ditujukan kepada mereka. Program komunikasi yang bagiamanapun akan menjadi sia-sia jika tidak disertai dengan strategi yang matang tentang khalayak ini. Di dalam masyarakat ada kelompok-kelompok yang menentukan besarnya pengeruh suatu program. Kelompok-kelompok tersebut yaitu: kelompok yang memberi izin, kelompok pendukung, kelompok oposisi dan kelompok evaluasi.

Untuk mengetahui khalayak biasanya pelaku komunikasi melakukan segmentasi masyarakat melalui proses penelitian dan pengamatan. Hasil dari proses tersebut menjadi landasan untuk meyusun strategi yang tepat. Biasanya ada tiga cara yang digunakan dalam memetakan karakteristik masyarakat, 
yaitu: aspek demografis (jenis kelamin, usia, pekerjaan, pendidikan, pendapatan, agama, ideologi, etnis dan termasuk pemilikan media), aspek profil psikologis (mencakup sikap yang tercermin dari kejiwaan masyarakat, missal temperamen, tenang, sabar terbuka, emosional, tidak sabar, dendam antipasti, terus terang, tertutup, berani dan penakut), aspek karakteristik perilaku masyarakat mencakup kebiasaan-kebiasaan yang dijalani dalam kehidupan suatu masyarakat (misalnya agamis, santun, suka pesta dan mabuk-mabukan, suka menabung, suka protes, tenggang rasa pelit dan ekonomis, boros, suka menolong, solidaritas tinggi, individual, jujur dan tanggung jawab. Dengan mengetahui peta khalayak, maka seorang perencana komunikasi dapat memprediksi dan mengantisipasi serta menyesuaikan program-program komunikasi yang akan dilakukan.

\section{Menyusun Pesan}

Pesan adalah suatu yang disampaikan kepada khalayak yang nantinya juda akan dipersepsikan. Pesan dibuat sesuai dengan tujuan kampanye dan khalayak yang dituju. Jika tujuannya adala komersil (ajakan untuk membeli), maka pesannya harus persuasif dan provokatif. Jika tujuan komunikasi adalah untuk menyadarkan atau melakukan penyuluhan terhadap masyarakat, maka pesannya harus bersifat persuasif dan edukatif. Jika tujuannya dalah sekedar memberikan informasi kepada masyarakat, maka pesan yang dibuat bersifat informatif.

Ada beberapa cara yang dapat digunakan dalam penyusunan pesan yang memakai teknik persuasi, antara lain: (1) Pesan yang menakutkan, yaitu metode penyusunan pesan yang dapat menimbulkan rasa ketakutan kepada khalayak. (2) Pesan yang penuh dengan emosi, yaitu penyusunan pesan yang berusaha mengunggah emosi khalayak, misalnya dengan mengungkapkan masalah agama, etnis, kesenjangan ekonomi, diskriminasi dan sebagainya. (3) Pesan yang penuh dengan janji, yaitu penyusunan pesan yang berisi janji-jani kepada khalayak. Riset Heilmen dan Gerbner (1975) menemukan bahwa khalayak cenderung menerima pesan atau ide yang penuh janji-janji dari pada pesan yang disertai ancaman. (4) Pesan yang penuh dorongan, yaitu teknik penyusunan pesan yang dibuat bukan karena janjijani, tetapi disusun untuk menumbuhkan pengaruh internal psikologis khalayak sehingga mereka mengikuti pesan-pesan yang disampaikan, dan (5) Pesan yang penuh humor, yaitu teknik penyusunan pesan yang berusaha membawa khalayak tidak merasa jenuh. Pesan yang disertai humor lebih mudah diterima, enak dan menyegarkan. Hanya saja harus diperhatikan kuantitasnya, jangan sampai humor jauh lebih banyak dari materi yang ingin disampaikan.

Terdapat dua bentuk teknik penyampaian pesan. Pertama one side issue, yaitu teknik penyampaian pesan dengan menonjolkan salah satu sisi, apakah kebaikan atau keburukan. Yang kedua, two-side issue, yaitu teknik penyampaian pesan dengan menggunakan kedua sisi tersebut. Selain mengemukakan yang baik-baik, seorang komunikator juga menyampaikan hal-hal yang kurang baik. Sisi yang kedua ini memberikan peluang kepada khalayak untuk berfikir apakah ada keuntungan yang nantinya mereka terima jika mereka melaksanakan informasi yang disampaikan.

\section{Strategi dan Produksi Media}

Sama seperti strategi pesan komunikasi, dalam memilih media komunikasi juga harus mempertimbangkan karakteristik, tujuan isi pesan dan jenis media yang 
dimiliki oleh khalayak. Pengetahuan tentang pemilikan media di kalangan masyarakat harus diketahui terlebih dahulu. Sebagai contoh untuk mencapai masyarakat luas sebaiknya menggunakan media massa seperti surat kabar atau televisi. Sedangkan untuk masyarakat komunitas atau kelompok dapat menggunakan media selebaran atau saluran komunikasi kelompok. Pertimbangan pemilihan media yang tepat berguna untuk menghindari terjadinya kesalahan dalam memilih media, menghindari terjadinya pemborosan biaya, watu dan tenaga. Tidak ada gunanya memakai media televisi, jika siaran yang dimaksudkan tidak diterima oleh masyarakat. Tidak ada artinya menggunakan media surat kabar untuk masyarakat yang tidak tahu membaca.

UNESCO memberi petunjuk bahwa dalam melakukan pemilihan media komunikasi, beberapa hal perlu mendapat perhatian, yaitu: (1) Sumber saya komunikasi yang tersedia disuatu tempat. Komunikator harus mengumpulkan berapa banyak stasiun radio, televisi surat kabar yang beredar di masyarakat. Berikut juga dengan sumber daya komunikasinya dan membuat analisis terkait informasi apa yang dibutuhkan oleh masyarakat dan bagaimana opini yang berkembang. (2) Pemilikan media di kalangan masyarakat atau berapa banyak penduduk yang memiliki media massa.

(3) Keterjangkauan pesan yang disampaikan melalui media massa. Apakah seluruh siaran yang ditayangkan mampu menjangkau/ diterima oleh seluruh masyarakat.

Perlu diketahui bahwa dalam menyampaikan pesan komunikasi banyak sekali media yang dapat digunakan, yaitu: (1) Media lama, yang terdiri dari media cetak, media elektronik, media luar ruang, media format kecil seperti bulletin, leaflet, selebaran, brosur poster dan lain-lain, kemudian saluran komunikasi kelompok, komunikasi public, komunikasi antarpribadi dan komunikasi tradisional. (2) Media baru (internet), yaitu teknologi interaktif dan komunikasi jejaring (network communication) yang menggunakan sistem komputerisasi dan jaringan.

Setelah menetapkan media mana yang akan digunakan, langkah selanjutnya adalah memproduksi media tersebut untuk proses penyebarluasan kepada khalayak. Penyebaran media komunikasi akan menentukan keberhasilan suatu program komunikasi. Penyebaran media cetak sama dengan penyebaran media elektronik, demikian juga dengan penyebaran media elektronik tidak akan sama dengan media luar ruang.

\section{Efek}

Strategi yang terakhir adalah berhubungan dengan efek yang ditimbulkan. Semua program komunikasi yang dilakukan mempunyai tujuan, yakni mempengaruhi target khalayak. Pengaruh atau efek adalah perbedaan antara apa yang dipikirkan, dirasakan dan dilakukan oleh penerima sebelum dan sesudah menerima pesan. Pengaruh sangat penting dalam proses komunikasi. Tujuannya ntuk mengetahui berhasil atau tidaknya kegiatan komunikasi yang dilakukan.

Pengaruh dapat terjadi dalam bentuk perubahan pengetahuan (knowledge), sikap (attitude) maupun perilaku (behavior). Pada tingkat pengetahuan perubahan dapat terjadi dalam bentuk perubahan persepsi dan perubahan pendapat. Adapun perubaha sikap adanya perubahan internal pada diri seseorang yang berupa bentuk prinsip, kepercayaan, ideology evaluasinya terhadap suatu objek. Perubahan perilaku adalah perubahan dalam bentuk tindakan yang dilakukan oleh khalayak. 
Ada empat macam efek perubahan yang bisa ditimbulkan, yaitu: (1) Turbulent. Suatu perubahan yang begitu cepat dan luas dalam suatu lingkungan yang memerlukan perencanaan jangka pendek, yakni antara 1-2 tahun. (2) Unstable. Yaitu cepat tapi perubahannya kecil sehingga diperlukan perencanaan untuk 2-3 tahun. (3) Transitional. Lambat tapi perubahnnya luas sehingga diperlukan perencanaan untuk jangka waktu 3-5 tahun. (4) Stable. Lambat dan perubahan yang ditimbulkan kecil, sehingga perencanaan diperlukan untuk jangka waktu 5-20 tahun.

Dari berbagai studi yang dilakukan terhadap pengaruh dalam komunikasi, ditemukan bahwa komunikasi massa lebih banyak berpengaruh terhadap pengetahuan dan wawasan seseorang. Sedangkan komunikasi antarpribadi cenderung berpengaruh pada sikap dan perilaku. Sebuah studi juga pernah dilakukan dengan temuan bahwa mendengarkan pidato langsung ditengah lapangan terbuka cenderung membakar emosional pendengar daripada melalui radio. Studi Lazarsfeld dan Katz di Eric Countrymenemukan bahwa kontak pribadi (komunikasi interpersonal) lebih tinggi pengaruhnya dalam mengajak seseorang untuk memilih calon presiden AS pada tahun 1944 daripada melalui media massa.

Agar mendapatkan tujuan yang diinginkan, maka keseluruhan itemitem dalam strategi yang sudah dijabarkan dikaitkan dengan fungsi manajemen Planning, Organizing, Actuating, dan Controlling (POAC), yakni: (1) Menyusun perencanaan untuk komunikator, pesan, media, khalayak, dan rencana pengaruhnya. (2) Mengorganisasikan komunikator, pesan media, khalayak, dan pengaruh yang diinginkan. (3) Menggiatkan komunikator, pesan, media, dan pengaruh yang diinginkan. (4) Mengontrol/ mengawasi komunikator, penyajian pesan, pemilihan dan penggunaan media, pemilihan dan penetapan khalayak, serta pengaruh yang diharapkan (Misnawati, 2013).

\section{Kampanye Sosial}

Kampanye dapat didefenisikan sebagai keinginan seseorang atau sekelompok orang untuk mempengaruhi kepercayaan dan tingkah laku orang lain dengan daya tarik yang komunikatif, dengan tujuan menciptakan perubahan atau perbaikan dalam masyarakat. Kampanye yang dimaksudkan di sini adalah ideological or cause campaigns, yang merupakan jenis kampanye yang memiliki goals yang bersifat khusus dan berdimensi perubahan sosial. Kampanye jenis ini diistilahkan oleh Kotler sebagai social change campaigns, yaitu kampanye yang bertujuan untuk menangani masalahmasalah sosial melalui perubahan sikap dan perilaku masyarakat.

Kegiatan kampanye bertujuan untuk merubah perilaku masyarakat dan berakar dari isu-isu sosial yang ada di masyarakat. Menurut Kotler dan Armstrong (2012:592) ada dua gerakan akar rumput yang utama yang dapat mendukung semua ini terjadi dan salah satunya adalah environmentalism, yaitu gerakan terorganisir yang melibatkan pemerintah dan masyarakat untuk melindungi dan meningkatkan lingkungan hidup masyarakat saat ini dan di masa datang. Gerakan ini bukan gerakan melawan pemasaran dan konsumsi, tetapi lebih kepada menuntut masyarakat dan produsen untuk lebih menghargai lingkungan (Kotler dan Armstrong, 2012: 583).

\begin{tabular}{llrr}
\multicolumn{1}{c}{ Gerakan } & sosial & sendiri harus \\
dipahami & sebagai & sebuah & $(1)$ \\
kolektivitas & orang yang bertindak \\
bersama; $(2)$ tujuan tindakan & adalah perubahan \\
bersamanya & adah \\
tertentu dalam masyarakat dengan cara \\
yang sama; (3) kolektivitas relatif \\
tersebar namun lebih rendah \\
derajatnya daripada organisasi formal;
\end{tabular}


(4) tindakannya mempunyai derajat spontanitas relatif tinggi namun tak terlembaga dan bentuknya tak konvensional. Jadi gerakan sosial adalah tindakan kolektif yang diorganisir secara longgar, tanpa cara terlembaga untuk menghasilkan perubahan dalam sebuah masyarakat (Octavianti, 2014: 46).

\section{METODE PENELITIAN}

Penelitian ini menggunakan pendekatan kualitatif dengan metode studi kasus. Penelitian ini menghasilkan data deskriptif yang didapat melalui wawancara mendalam (tak terstruktur) dengan Penggiat Gerakan Indonesia Diet Kantong Plastik. Data penelitian juga didapat melalui penelurusan dokumen,

Teknik analisa data menggunakan model interaktif, yaitu dengan data reduction, data display, dan conclution drawing and verifying (Denzim \& Lincoln (terjemahan), 2009). Data yang penulis kumpulkan dipilah-pilah ke dalam satuan konsep, kategori atau tema tertentu, kemudian ditampilkan sehingga terlihat sosoknya. Pada tahapan ini data yang telah dikelompokkan kemudian disusun dalam bentuk narasi dengan menggunakan kalimat yang logis dan sistematis, sehingga terdapat gambaran yang jelas menuju langkah terakhir, yaitu penegasan terhadap kesimpulan. Kesimpulan mampu menggambarkan dengan jelas tentang strategi komunikasi dalam kampanye diet kantong plastik.

\section{PEMBAHASAN}

\section{Kampanye Diet Kantong Plastik}

Gerakan Indonesia Diet Kantong Plastik (GIDKP) adalah perkumpulan nasional yang memiliki misi untuk mengajak masyarakat agar lebih bijak dalam menggunakan kantong plastik. Mengambil peran strategis hanya pada masalah kantong plastik, menjadi peluang besar bagi GIDKP untuk dapat melebarkan sayap ke wilayah-wilayah yang menjadi sasaran kerja untuk mengampanyekan Diet Kantong Plastik di Indonesia. Gerakan ini diinisiasi oleh PT. Greneration Indonesia, PT. Daun Plus (Leaf Plus), PT. Monica Hijau Lestari (The Body Shop Indonesia), Change.org, Ciliwung Institute, Earth Hour Indonesia, Indorelawan, Kreasi Daur Ulang, Si Dalang, Tiza Mafira dan Joko Arif Pada tahun 2013 (dietkantongplastik.info, tanpa tahun).

Gerakan Indonesia Diet Kantong Plastik memiliki visi, misi dan Tujuan sebagai berikut:

$\begin{aligned} \text { Visi } & \text { : Indonesia Bebas Kantong } \\ & \text { Plastik } \\ \text { Misi } & \text { Mengajak Masyarakat agar } \\ & \text { lebih bijak dalam } \\ & \text { menggunakan kantong plastik } \\ \text { Tujuan : } & \text { Menyelamatkan Lingkungan } \\ & \text { dari bahaya sampah kantong } \\ & \text { plastik }\end{aligned}$

Dari Visi, Misi dan Tujuan GIDKP tersebut kelihatan bahwa kampanye dan program-program yang dilakukan oleh gerakan ini hanya menyasar pada permasalahan kantong plastik saja. Karena fokus tersebut penggiat Gerakan Diet Kantong Plastik menyusun strategi dalam berkampanye, yang dikenal dengan pendekatan strategis (Kurniadi \& Hizasalasi, 2017).

1. Regulasi. Regulasi adalah strategi kampanye yang dijalankan dengan upaya (advokasi) kepada pemerintah. Upaya ini dilakukan agar peraturan berkaitan dengan pengurangan kantong plastik dapat dikeluarkan oleh pemerintah.

2. Edukasi. Edukasi adalah upaya terus-menerus untuk memberikan pengetahuan dengan bentuk metode, pelatihan, presentasi, diskusi kelompok, pemutaran film lingkungan, membuat karya daur ulang dari bahan bekas, 
EnviroChalange

mengembangkan

kelompok relawan.

3. Fasilitasi. Fasilitasi adalah strategi yang diarahkan kepada dunia bisnis (peritel). dunia bisnis menjadi sektor penting untuk disadarkan, karena siklus penggunaan kantong plastik oleh masyarakat berasal dari penjual. Gerakan Indonesia Diet Kantong Plastik, mengajak usaha Ritel di Indonesia untuk berperan aktif mengampanyekan pengurangan penggunaan kantong plastik ketika ada masyarakat yang berbelanja dan juga memberikan penghargaan bagi peritel yang berhasil menjalankan Diet Kantong Plastik.

\section{Strategi Komunikasi Dalam Kampanye}

Tujuan kampanye Gerakan Diet Kantong plastik dapat dicapai melalui sebuah strategi komunikasi. Dijelaskan dalam kerangka teori bahwa strategi komunikasi merupakan kombinasi yang terbaik dari seluruh elemen komunikasi yang dirancang untuk mencapai tujuan komunikasi yang optimal, maka pembahasan berikutnya bertitik tolak pada strategi yang diarahkan pada formula Lasswel, yaitu strategi yang berhubungan dengan komunikastor, pesan, media, khalayak dan efek.

Pemilihan komunikator yang tepat menjadi alasan penting karena merupakan ujung tombak yang membuat pesan kampanye nantinya menjadi efektif atau tidak. Pada prinsipnya GIDKP merupakan teamwork yang bekerja secara bersama-sama dalam kampanye Diet Kantong Plastik. Semua pihak menjadi komunikator Kampanye Diet Kantong Plastik, yang menjadi permbedanya adalah secara formal dalam kampanye-kampanye tertentu, maka bagian/ tim harian yang akan mengomunikasinnya kepada khalayak.
Tim harian dalam susunan organisasi menjadi komunikator pesan kampanye Diet Kantong Plastik. Standar utama dalam menjalankan strategi ini adalah kemampuan berkomunikasi dalam menyajikan informasi yg aktual terkait isu kantong plastik. Komunikator memegang prinsip harus menyampaikan informasi yg benar, valid dan sesuai dengan data. Komunikator memiliki sifat terbuka tentang keterbukaan informasi yang harus diketahui oleh masyarakat.

Strategi pesan yang informatif, edukatif dan persuasif dipersiapkan oleh GIDKP dalam kampanye Diet Kantong Plastik. Pesan dibuat dengan gaya persuasif itu artinya khalayak diposisikan sama karena pada dasarnya setiap individu juga berperilaku tidak bertanggung jawab awalnya dalam menggunakan kantong plastik, akan tetapi setelah memahami pentingnya mengurangi kantong plastik dalam kehidupan sehari-hari dan menjadi penggiat Diet Kantong Plastik maka mampu mengurangi tingkat penggunaan kantong plastik.

Khalayak diedukasi dengan penggunaan bahasa yang tidak formal dan diisi dengan konten-konten yang menarik. Pentingnya memperhatikan psikologis masyarakat, karena masyarakat cenderung bosan dengan pesan yang disampaikan dengan bahasa formal. Strategi pesan juga dilakuan dalam mempertimbangkan intensitas kemunculan pesan. Pada prinsipnya setiap media memiliki pesan yang sama, tetapi dengan karakteristik yang membuat pesan dikemas dengan gaya yang berbeda.

Perencanaan pesan dipersiapkan dengan pengumpulan data-data yang valid. Data ini menjadi ukuran kredibilitas informasi karena masyarakat harus mendapatkan informasi yang faktual. Pembuatan pesan juga mempertimbangkan 
informasi yang aktual (baru). Informasi baru cenderung disukai oleh khalayak. Maka penempatan isu dan perkembangan zaman disertai dalam pembuatan pesan kampanye.

Langkah berikutnya adalah menyusun semua data yang telah dikumpulkan dan menjadikannya dokumen dalam berbagai bentuk. Yang pada akhirnya setiap pesan direncanakan sesuai dengan jenis media yang digunakan untuk berkampanye. Selain itu, waktu juga menjadi perhatian GIDKP, karena pesan ini adalah pesan kampanye, maka momentummomentum yang tepat dibidik sehingga tersampaikan dengan efektif.

Informasi yang berhubungan dengan Diet kantong plastik disampaikan melalui beragam media yang ada, tujuannya adalah dengan terpaan media akan menyebabkan pesan kampanye diketahui oleh masyarakat. Media di sini dimaksudkan tidak hanya media dalam bentuk fisik seperti media massa, melainkan juga media lain yang berbentuk event-event tertentu.

Strategi media dilakukan dengan memilih seluruh jenis media yang ada dan yang paling dekat dengan masyarakat. Setiap media tentu memiliki karakteristik masing-masing.

Berikut media yang digunakan dalam kampanye Diet Kantong Plastik:

1. Media sosial (Twitter, Youtube, Facebook, Instagram, Line,)

2. Press release

3. Newsletter

4. Website

5. Konferensi pers

6. Poster dan Foto

7. Komunikasi interpersonal

8. Petisi

9. Media kampanye lainnya, seperti pada tas belanja, baju kaos dan lain-lain
Selain menggunakan media secara langsung, strategi kampanye dilakukan dengan bentuk media engagement. Bentuk ini dilaksanakan dengan mengundang media untuk ikut meliput dan terlibat secara langsung. GIDKP memberikan ruang bebas kepada media, karena tujuan untuk mengampanyekan ini seharusnya tidak hanya dimiliki oleh penggiat melainkan juga harus tertanam bagi pihak-pihak yang memiliki kemampuan strategis untuk mempengaruhi masyarakat. GIDKP menggunakan tokoh-tokoh terkenal yang memiliki posisi strategis. Upaya ini dilakukan agar menarik perhatian media untuk meliput.

Seluruh masyarakat, pemerintah dan usaha ritel adalah khalayak menjadi sasaran dalam Kampanye Diet Kantong Plastik. Target kampanye Diet Kantong Plastik adalah semua kalangan, tetapi setelah di kerucutkan bahwa yang paling banyak menggunakan kantong plastik adalah ibu-ibu dan anak muda. Dua ini adalah target utama dalam kampanye Diet Kantong Plastik. Prinsipnya adalah bahwa setelah ibuibu diedukasi, maka secara tidak langsung akan mempengaruhi orangorang yang di rumahnya. Konsep strategi dirancang dengan penyesuaian terhadap hal-hal spesifik yang ada juga di tengah masyarakat.

Pada dasarnya strategi khalayak/ sasarn tidak dengan penentuan, melainkan jika ada daerah yang tertarik dengan isu pengurangan sampah kantong plastik, maka akan menjadi sasaran kampanye. Upaya advokasi kepada pemerintah cenderung lebih diinginkan karena pemerintah seharusnya lebih proaktif untuk mengampanyekan isu pengurangan sampah palastik kepada masyarakat dan peritel di daerah manapun.

Tapi tidak bisa dinafikkan bahwa, fokus pada kota-kota besar terlebih dahulu seperti Bandung dan Jakarta 
kemudian baru menyasar ke daerahdaerah. Bandung dan Jakarta dipilih karena dua kota ini memang ring merah (fokus utama). Sebagai kota besar, maka siklus penggunaan kantong plastik juga sangat besar di kota ini. Selain itu kota ini akan menjadi prorotype kampanye sampai pada kabupaten/ kota di Indonesia. Jika penerapan Diet Kantong Plastik berhasil di kota besar, maka untuk diadobsi oleh pemerintah daerah dan masyarakat jauh akan lebih mudah.

Faktor domisili juga menjadi pertimbangan, daya jangkau yang dimiliki oleh GIDKP juga masih terbatas. Sebetulnya GIDKP memiliki mitra organisasi di daerha tapi dalam kategori sangat terbatas. GIDKP memiliki mitra yang rata-rata masih berada di pulau Jawa, seperti Malang, Surabaya, Tasik, Bali dan satu di Papua. Untuk sumatera belum ada gerakan yang fokus dan konsen terhadap isu sampah kantong plastik.

Yang terakhir adalah hal yang berhubungan dengan efek komunikasi. Hasil yang dicapai oleh GIDKP menunjukkan bahwa dalam level makro kampanye Diet Kantong Plastik mampu berjalan dengan maksimal. Beberapa perubahan dapat terwujud. Tahun 2010 Pemerintah Kota Bandung mengeluarkan Surat Himbauan untuk mengurangi penggunaan kantong plastik. Kemudian Pemerintah Kota Bandung mengeluarkan Perda No.17 Tahun 2012 tentang Pengurangan Penggunaan Kantong Plastik. Tahun 2013, Pemerintah Provinsi DKI Jakarta mengeluarkan Surat Seruan No.6 tahun 2013 tentang Gerakan Diet Kantong Plastik pada perhelatan Festival Jakarta Great Sale 2013 selama satu bulan pada bulan Juli 2013. Kemudian, di tahun 2014 mengeluarkan Surat Seruan Gubernur No.1 Tahun 2014 tentang Gerakan Jakarta Diet Kantong Plastik. Kemudian sebagi respon dari petisi \#pay4plastic, Kementerian Lingkungan
Hidup dan Kehutanan mengeluarkan surat edaran tentang langkah antisipasi penerapan kebijakan kantong plastik berbayar pada usaha ritel modern yang ditujukan kepada Gubernur, Bupati/ Walikota, dan pelaku usaha. Melalui surat edaran ini setiap daerah harus bersiap untuk melaksanakan kewajiban kantong plastik berbayar dengan disertai komunikasi, informasi, dan edukasi public untuk peningkatan pemahaman akan pentingnya pengurangan penggunaan kantong plastik.

\section{KESIMPULAN}

Kesimpulan penelitian ini adalah strategi komunikasi dalam kampanye diet kantong plastik yang dilakukan oleh GIDKP di Indonesia melebur dengan pendekatan regulasi/ advokasi, edukasi dan fasilitasi yang menjadi titik poin kampanye GIDKP. Perhatian penting pada setiap unsur komunikasi direncanakan dengan strategi yang saling menunjang. Pemilihan komunikator berdasarkan resource yang ada dan pada prinsipnya semua adalah komunikator pesan. Komunikator menyampaikan informasi yang benar, valid, berdasarkan data dan memiliki sifat terbuka tentang informasi tersebut. Kemudian strategi pesan dibuat tetap dengan kaedah pesan harus memiliki sifat edukatif, informatif dan persuasif. Pesan disampaikan melalui seluruh media yang ada, mulai media konvensional hingga media baru. Strategi pesan dibuat dengan prinsip bahwa pesan dirancang dengan bentuk yang sangat simple dan tidak fomal, agar masyarakat tidak jenuh.

\section{DAFTAR PUSTAKA}

Cangara, Hafied. (2014). Perencanaan \& Strategi Komunikasi. Depok: PT. Raja Grafindo Persada

Denzin, Norman K and Lincoln, Yvonna $S$ (eds.). (1997). Handbook of Qualitative Research. Terjemahan 
oleh Dariyatno dkk (2009), Yogyakarta: Pustaka Pelajar

Diet Kantong Plastik, Tentang Kami, diakses dari http://dietkantongplastik.info/tent ang-kami/, tanggal 20 Juni 2017.

Kotler, Philip \& Gary Armstrong. (2012). Principles of Marketing 14th ed. New Jersey: Pearson Education

Kurniadi, Hayatullah \& Mohamad Hizasalasi. (2017). Strategi Kampanye Diet Kantong Plastik oleh GIDKP di Indonesia. Prosiding Seminar Nasional 2nd CelscitechUMRI 2017
Misnawati, Indah Tri. 2013. Strategi Komunikasi Pada Kampanye Perlindungan Orangutan Oleh Lsm Centre For Orangutan Protection (Cop)Di Samarinda, alimantan Timur. Jurnal Ilmu komunikasi, 2013, 1 (4): 135-149

Octavianti, Meria. (2014). Alur Pesan Kampanye Gerakan Cikapundung Bersih Dalam Meningkatkan Kesadaran Kebersihan Lingkungan. Jurnal Komunikasi Universitas Tarumanagara, Tahun VI/02/2014 